\title{
問題解決のための階層型自律分散システムの構成
}

\author{
増 市 博*・片 井修** 椹木哲夫** \\ 西山高 史*** 岩 井壮 介**
}

\section{A Multi-Layered Autonomous Decentralized System Architecture for Problem Solving}

\author{
Hiroshi Masuichi*, Osamu KataI**, Tetsuo Sawaragi**, \\ Takashi NISHIYAmA*** and Sosuke IWAI**
}

This paper introduces a novel approach of problem solving based on Autonomous Decentralized System framework, where an Autonomous Decentralized System consists of autonomous subsystems whose cooperation yields the structuredness (order) of the entire system without any control by supervisor. Thus the system is expected to have high efficiency, reliability and flexibility. We propose a general framework for Autonomous Decentralized Systems. By the use of "slaving principle", the central concept in Synergetics introduced by Haken, the proposed system forms its order without central control by supervisor. Moreover, the concepts of layered structure, "the dual control" and "the pinciple of marginal control" make it possible for the proposed system to realize the compatibility between "autonomy" and "cooperation", that is the most difficult point to be attained in Autonomous Decentralized Systems. Also, we implement concrete systems for solving several different kinds of problems on Transputers using the parallel processing language OCCAM, which show the effectiveness of our approach.

Key Words: autonomous decentralized system, slaving principle, problem solving, dual control, the principle of marginal control

\section{1. はじめに}

近年の半導体技術や通信技術の著しい発展を背景に, いわゆる並列あるいは分散型のシステム構成概念に基づ いた問題解決に関する研究が多くなされている.しかし， このような分散・並列化されたシステムの多くは，シス テム全体の目標を明確化した上で部分にその機能を割り 当てるという考え方に基づいて設計されている。つまり システムに固定的に与えられた全体目標を達成するため にシステムをいくつかのサブシステムに分割し，その後 にサブシステムの機能・構造を決定する。このようにトッ

$\dagger$ 第 13 回知能システムシンポジウムで発表 $(1991 ・ 3)$

* 富士ゼロックス(株) 横浜市保土谷区神戸町 134

** 京都大学工学部 京都市左京区吉田本町

*** 松下電工(株) $\quad$ 門真市大字門真 1048

* Fuji Xerox Co. Ltd., Yokohama

** Faculty of Engineering, Kyoto University, Kyoto

*** Matsushita Electric Works, Ltd., Kadoma (Received February 12, 1992)

(Revised May 20, 1992)
プダウン的に設計されたシステムでは，一般に多様に変 化する目標・環境に適応することが困難となる。これに 対し, 自律分散システムはまったく新しいシステム構成 概念として最近注目を集めている11.これは，まず“自律” したサブシステムが存在し，それらの“協調”の結果とし て秩序だった全体システムが構成されるという考え方に 基づいている。この特徵に由来して, 高効率性, 信頼性, 耐故障性，拡張性，柔軟性などの効能が期待されてい る ${ }^{2)}$.しかし, 現在のところ概念だけが先行し, 定義も曖 昧で, 具体的システム構築例は少数に留まっている。

このように自律分散システムの考え方が普及していな い原因として, 各サブシステムの“自律性”とこれらの間 の “協調性” の共存の困難さが挙げられる3). 自律は全体 の拘束から離れ個々の責任において自由に振る舞うこと を意味し，協調は逆に自己を抑え全体の目標に協力する ことを意味する，自律分散システムでは，この相反する 二つの概念を共存させなければならない.

本研究では秩序だった全体システムを自己組織的に生 成するための枠組みとして，H. Hakenの Synergetics 
に括る中心概念であるスレイビング原理 ${ }^{4}$ を導入し， 自律分散システムの構成概念を提案する。さらに, “自律” と“協調”の共存を可能とし，実際にスレイビング原理を 成立させて秩序形成を達成するために必要な概念とし て, 自律分散システムの典型例ともいえる生物界につい ての考察をもとに, システムの階層構造化抢よび二重制 御（dual control）とそれを支える周縁制御の原理（the principle of marginal control) $)^{5}$ を導入する.

さらに本研究では, 問題解決一般に潜む以下の二重性 に着目することにより，自律分散システムを問題解決シ ステムと考える。すな斿ち，部分問題の解が满たすべき 制約条件のもつ局在性(局所的整合性) ここれら解(局所 解)の集合が全体として满たすべき整合性(大局的整合 性) という二つの側面から問題解決を捉え,これを部分問 題を解くサブシステムの局所的な自律性とシステム全体 の協調性に対応させることにより, 自律分散型問題解決 システムの構成原理とその具体的構築を検討する。

以下第 2 章に扔いて, 本問題解決システムの構成原理 の提案を行う。第 3 章では提案システムに扔ける秩序形 成の中心概念であるスレイビング原理について概説す る。また，秩序形成の際の“自律”と“劦調”の共存の実現 に不可欠な要素であるシステムの階層性, 二重制御, 周緑 制御の原理などの諸概念を説明し，これらと提案システ ムとの関係を明らかにする。第 4 章ではとくに，制約条 件の局在性と局所解の集合が満たすべき整合性という二 重性をもつ問題範疇として制約充足問題と多自由度制御 問題を取り上げ，提案した構成原理をそれぞれ具体的問 題に適用し, 問題解決システムの構築を行い, その有効性 を検討する。構築システムはすべて並列処理言語OCCAM ${ }^{6}$ によってトランスピュータ上に実現されている。

\section{2. 自律分散型問題解決システムの構成原理の提案}

本研究では，Fig.1（a）のような二層構造をもつ自律 分散システム構成を提案する。図中の丸印は，すべて非 同期並行的に計算を実行するプログラムプロセスを表わ し，プログラムプロセス間を結ぶ線分は，情報伝達を受 けもつ通信テャンネルを示す。プログラムプロセスは 2 種存在し，それぞれをミクロダイナミクスプロセス(micro dynamics process), マクロオーダープロセス (macro order process) と呼ぶ. ミクロダイナミクスプロセスと マクロオーダープロセスはシステム中に同数存在し，宁 れぞれ一対一に対応づけられている。この対応する二つ のプロセスのペアを自律分散ユニット (autonomous decentralized unit : ADU) と呼ぶ。各自律分散ユニット はそ狆自身自律的な“全体”としての側面とユニット群全 体に対して協調的に動作する“部分”としての側面を合わ せもつものである(洋1). 自律分散ユニットの，ミクロダイ ナミクスプロセスが自律的側面，マクロオーダープロセ スが協調的側面の役割を果たす。本提案システムは，通 信チャンネルによって結合された多数の自律分散ユニッ 卜がーつの平面上に並んだ単階層構造を形成していると みることもできる(Fig.1(b))。なお，マクロオーダー プロセスの並ぶ平面をマクロオーダーレイヤ（macro order layer)，ミクロダイナミクスプロセスの前ぶ平面 をミクロダイナミクスレイヤ(micro dinamies layer) と 呼ぶ.

（注 1）A. Koestler はこのような二側面をもつシステム满 成要素を“ホロン”と命名した。しかし，ホロンの場 合,こ机らがホラーキー階層構造をなすことを前提と しておりっここでのシステム構成原理とはかなり異な ることからここでは“自律分散ユニット”と呼ぶこ とにした。

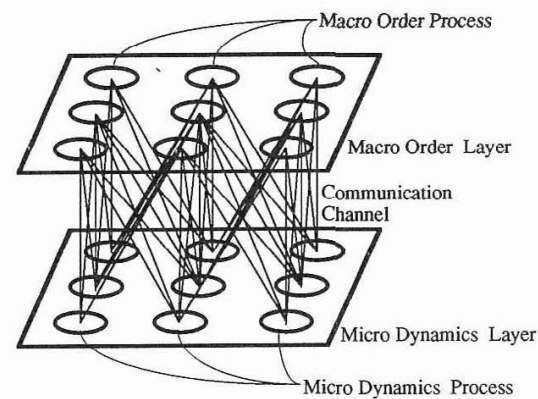

(a) Two-layered structure of the proposed system

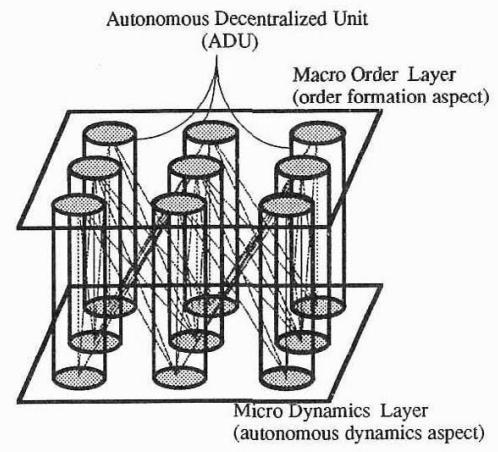

(b) Two-aspect structure of the proposed system

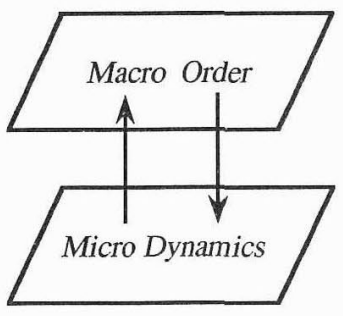

(c) Formation of the slaving principle

Fig. 1 Structure of the proposed system and the illustration of Slaving Principle 
これら 2 種のプログラムプロセスは以下のように動作 する.すなわち，マクロオーダープロセスは各自律分散 ユニットの内部状態を保持する機能をもち，一種の分散 型共有メモリとなっている.これに対してミクロダイナ ミクスプロセスはマクロオーダープロセスが保持する内 部状態を変更する機能をもつ。ここで，内部状態変更を 実行するアルゴリズムは

（1）自己触媒性

（2）全体目標指向性

の二つの性質を満足していなければならない. 自己触媒 性とは，システム全体のマクロ秩序に関して，各自律分 散ユニットが自己の内部状態をこの秩序を強めるよう変 更する性質で，全体目標指向性とはこの秩序形成がシス テム全体の目標達成をも指向するように, 内部状態変化 してゆく(ユニット動作に関する)性質である。一般に, 秩序を形成することのみに注目すれば自己触媒性だけが 重要となるが, 問題解決の観点からみれば秩序の指向性 と問題解決の指向性とは一致していなければならない. これに対応するものが全体目標指向性である.これらに ついては第 3 章および第 4 章で触れる.

Fig. 2 に，一つの自律分散ユニットに注目した場合の ミクロダイナミクスプロセス, マクロオーダープロセス

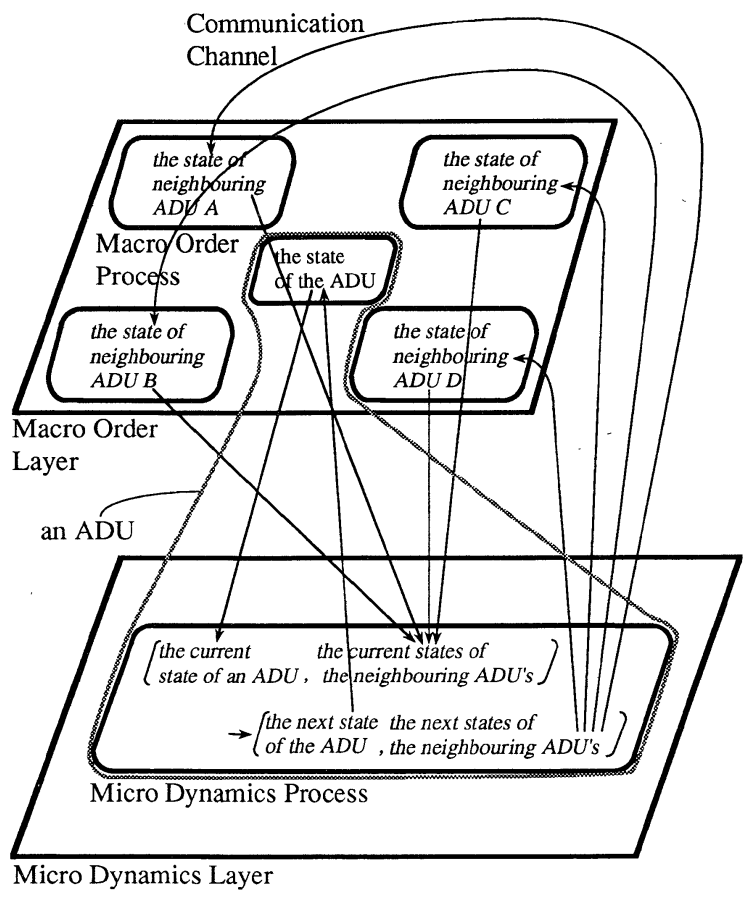

Fig. 2 Functions of Micro Dynamics and Macro Order Processes
の働きを図示する。一つのミクロダイナミクスプロセス は, 自分自身に対応するマクロオーダープロセスと, 隣 接するミクロダイナミクスプロセスに対応するマクロ オーダープロセスとにアクセスし，それらの内部状態を 受けとる、これら内部状態から, 自己触媒性と全体目標 指向性をあわせもつ状態遷移則に基づいて, 次期の自己 および隣接する自律分散ユニットの内部状態を決定す る. 決定された内部状態は, 再びもとの各マクロオーダ ープロセスへと返される。

つぎに，各平面の役割を説明する。ミクロダイナミク スレイヤでは，各ミクロダイナミクスプロセスの自律的 な内部状態変更機能により自律分散ユニットの局所的か つ部分としてのミクロダイナミクスの側面が実現され る、マクロオーダーレイヤでは，マクロオーダープロセ ス間の協調関係によってシステム全体のマクロな秩序の 形成の側面が実現される(Fig. 1(c))。提案システムで はミクロダイナミクスプロセスとマクロオーダープロセ スはすべて非同期並行的に動作する。まず，各ミクロダ イナミクスプロセスが自律的に計算を始める，各ミクロ ダイナミクスプロセスは，隣接する自律分散ユニットの 内部状態の影響を受けながら，自己触媒性と全体目標指 向性をあわせもつアルゴリズムに従って動作し，その結 果, マクロオーダーレイヤには一定の関係性(マクロな秩 序)が発現する.その後, 各ミクロダイナミクスプロセス は，自分自身の作り出したマクロな秩序に従う形で計算 を続け秩序の形成がさらに進行する。このミクロダイナ ミクスレイヤにおける.ミクロダイナミクスとマクロオー ダーレイヤにおけるマクロな秩序の間のフィードバック ループを形成したやりとりによって，統一管理機構の存 在なしに, システム全体の秩序形成と問題解決が可能と なる。

\section{3. 提案システムにおけるマクロ秩序形成原理}

\section{1 自己組織化現象とスレイビング原理}

提案システムに拈けるミクロダイナミクスとマクロな 秩序の間のやりとり(フィードバックループ)によって秩 序が徐々に形成されていく様子は自然界の秩序形成の際 にも見受けられる。これについては，自己組織化現象に 関する学問である H. Haken による Synergetics の中で スレイビング原理(隷従化原理, 隷属原理)として詳しい 研究がなされている4).

Synergetics は物理現象のみならず経済，社会システ ムにわたる幅広い範囲の自己組織化現象を統一的に扱う 学問分野であり，そこでの核心はスレイビング原理に よってシステムの振る舞いを説明づけることである.

Haken は自己組織化現象の簡単な例として,レーザを 
取り上げている.レーザ管の中でポンピングと呼ばれる 操作によって励起状態に置かれた原子は，もとの基底状 態に戻る際に誘導放出によって光を放出する.この場合, 外からの光と同じ位相の光が放出される.ポンピングに よって与えるエネルギが大きくなると，励起状態の原子 の密度の高い不安定構造となり，誘導放出が連鎖的にお こり, 原子の状態変化が協同的に進行する. その結果, レーザ管の両端にとりつけられたミラーの働きで，レー ザ管の軸方向にレーザ光(マクロな秩序)が発生する，こ のとき, 誘導放出の働きで, 原子のミクロな運動が, マ クロな秩序であるレーザ光に同調することになる，この 誘導放出は，マクロな秩序に自己のミクロダイナミクス を同調させる性質による，すなわち原子の運動のもつ自 己触媒性に基づくものと解釈される.

位相のそろった光の波というマクロな秩序は多数の原 子の内部運動というミクロダイナミクスから構成されて いる。またその一方で，ミクロダイナミクスはマクロな 秩序に隷従している，つまりマクロな秩序とミクロダイ ナミクスの間にフィードバックループが存在する (Fig. 1(c)). Haken は秩序形成に関してこのような隷従化現 象が起きているときにスレイビング原理が成立している といい，またこのスレイビング原理はレーザばかりでな く自己組織化現象一般に成立するものと主張している.

\section{2 生物界の階層構造と二重制御}

提案システムでは，スレイビング原理に示される構造 をシステム内に実現し, 秩序の自己組織的形成を行うこ とが基本的な構成原理である。しかしながら，前節で述 べた自己触媒性をもつ自律分散ユニットを多数非同期並 行的に動作させるだけでは秩序形成が常に生起するとは 限らない.レーザの例では, たとえばレーザ管両端のミ ラー間距離によって秩序生成の有無が制御される。すな わち, ミラー間距離が適切なときにのみレーザ光が発生 する.ここで重要なことはミラー間距離という単一の(マ クロな)変数の操作によって多数の原子のミクロダイナ ミクスを一括して制御できることである。

本節では，現実に低次な機能しかもたない構成要素が 集合することによってより高次の秩序を形成する生物界 についての考察を行い, システム中でスレイビング原理 に従う秩序形成を進行させるために必要となる諸概念を 示す。これはまた, 自律分散システムの構築を困難にし ている“自律”と“協調”の共存を可能とする概念でもある. 生物界を自律分散システムとして捉えるとき, 最も重 要なものはそのシステム構造のもつ階層性である. 動物 を例に階層性をみると Fig. 3のようになる. 図中, 丸で 囲んだ構成要素は各階層での自律分散ユニットに相当す るものである。ここでの層別化は, いずれの階層の設定

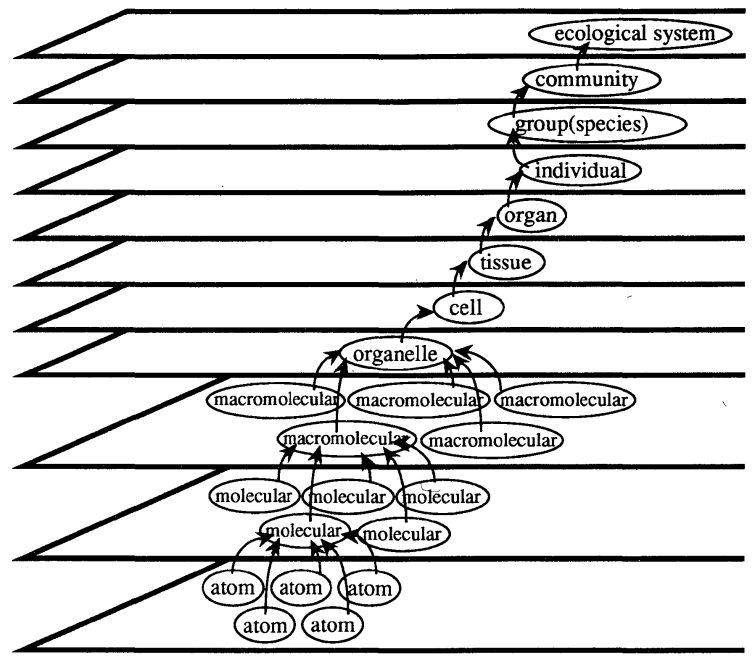

Fig. 3 Layered system structure of creatures

も，直上の階層が下位の階層にはないグローバル（大局 的・総体的)な性質をもつ自律分散ユニットが生成されてい ることを基準に行われている.このグローバルな性質をも つ自律分散ユニットの生成を秩序形成であると考えれば, この多階層構造において一対とみた隣接する各二階層は おのおのが(生物界全体の中に位置づけられた一つの)自 律分散システムを構成していると考えることができる.

このように一つの二階層のみに注目して自律分散シス テムのモデル化を行ったものが本提案システムである. すなわち，二階層の上位階層は，下位階層の構成要素の 集合の仕方(秩序の形態)を表現したものであり，提案シ ステムのミクロダイナミクスレイヤが下位階層に, マク ロオーダーレイヤが上位階層に対応する。すでに述べた ように，各自律分散ユニットのミクロダイナミクスの側 面を実現するものがミクロダイナミクスレイヤであり， 全体システムとしてのマクロな秩序の側面を実現するも のがマクロオーダーレイヤである.

生物界の階層構造を支える統御原理として注目すべき ことは，各階層それぞれが，下位の階層を構成する諸要 素を支配する法則と，自分自身の階層の諸要素そのもの に対して成り立つ法則に同時に制御されているというこ とである。これは二重制御 (dual control) と呼ばれる5). たとえば，動物の個体はその構成要素である器官を支配 する法則によって制御される。すなわち動物は構成要素 である各種器官のもつ機能の働きからのがれることはな い.それと同時に，個体はその個体自身を支配する法則 にも制御される，つまり，個体はその個体自身の行うこ とのできる行動や精神活動の枠を越えることはできな 
い.このようにして個体は二重制御を受けることになる。 また, 動物の種(個体の集団) は, 構成要素である個体が 行う行動や精神活動からはのがれることはできず，かつ その種に備わる特有の行動の型に逆らうこともできな い.つまり二重制御を受けている。このように，すべて の階層はそれぞれ二重制御を受けていると考えられる。

このような各階層が受ける二重制御は, 周縁制御の原 理に従っている ${ }^{5}$. つまり, 下位の階層は, 自身の諸構成 要素を支配する法則に従う。一方, 上位の階層の組織原 理は, 下位の階層に位置する自律分散ユニット間の境界 条件(boundary condition)を決定する。ここで境界条件 とは，下位の階層では確定されないままになっている諸 条件のことである.たとえば, 動物の個体の階層を上位, 器官の階層を下位とする二階層を考えれば，筋肉その他 の諸器官の機能は個体の運動が成り立ち得る可能性を開 いており，そのように確定されぬまま残されている境界 条件を個体の運動の組織原理(精神活動)が決定する.

\section{3 提案システムにおける二重制御の実現}

本研究では, 前節で述べた二重制御および周縁制御の 原理の概念を自律分散システムに導入することにより， スレイビング原理に従う秩序形成を制御し，また“自律” と“協調”の共存を可能にする.すなわち, システムの各 構成要素(自律分散ユニット)は下位の階層を支配する法 則に制御されてそれぞれ自律的に振る舞い, かつこの法 則の制御によっては確定されない境界条件が上位の階層 を支配する法則によって制御されることによって協調的 に秩序の形成を行うことになる。

再びレーザの例(原子の階層が下位, レーザ光の階層が 上位)を考えると,レーザ光は各原子の誘導放出という下 '位の階層を支配する法則に制御される。一方，その振る 舞いは, レーザ管両端のミラー間距離によって上位の階 層にも制御される (二重制御)。そして, 原子の階層の支

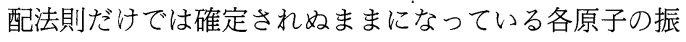
る舞いをミラー間距離の調整によって協調的に決定する ことができる(周縁制御の原理).

提案システムにおいては, 生成される秩序を制御する 下の階層(ミクロダイナミクスレイヤ)の法則は, 非同期 並行して動作するミクロダイナミクスプロセス内プログ ラムのアルゴリズムで規定される。一方, 上位の階層(マ クロオーダーレイヤ)を支配する法則は, マクロオーダー レイヤに発現する秩序(自律分散ユニットの関係性)を制 御する各ミクロダイナミクスプロセス内プログラムに共 通する各種パラメータにより与えられる。この共通パラ メータを操作することによって，ミクロダイナミクスプ ロセス内の自律的アルゴリズムに矛盾することなく，自 律分散ユニット間の協調的関係性を調整し周縁制御を行
うことができ，マクロオーダーレイヤへの秩序形成が可 能となる，このとき，レーザの場合と同様に，たとえば ミクロダイナミクスプロセス内プログラムの実行速度を 規定するパラメータのような単一の変数の操作により多 数の自律分散ユニットのミクロダイナミクスを一括して 制御することが可能となる.

以上の方法により，提案システムでは“自律”と“協調” の共存が実現可能となり，比較的単純な機能をもつ構成 要素である自律分散ユニットからマクロな秩序が生成さ れ, より複雑かつ柔軟なシステム機能が実現される.

\section{4. 並列処理言語による提案システムの具体的構築}

第 1 章でも述べたように, 本研究では部分問題の解(局 所解)が満たすべき制約条件の(ミクロな)局在性とこれ ら解が満たすべきマクロな整合性という二つの側面から 問題解決を捉え直し，これを自律分散ユニットのもつ自 律性とシステム全体が達成する協調性に対応させること により，自律分散システムを問題解決に適用する．本章 では, 提案システムのもつ特徵を生かした問題解決の対 象として制約充足問題と多自由度制御問題を取り上げ る。構築したシステムはすべて並列処理言語 OCCAM ${ }^{6)}$ によってトランスピュータ上に実現されている。

\section{1 制約充足問題に対する構築例}

ここで制約充足問題とは, 複数の構成要素からなる対 象に対する解釈, 解析, 設計などを, 付随する制約を充 足する解を求める問題として捉えたもので, 各構成要素 には局所的制約条件が課せられ，さらに対象物全体にも 何らかの全体的整合性, 最適性が求められる問題である.

提案システムの特徴は, ミクロダイナミクスレイヤ上 のミクロダイナミクスプロセスの自律的問題解決機能と マクロオーダーレイヤ上での秩序の生成であり，この特 徵を損なうことなく制約充足問題への適用を行う.つま り, 制約充足問題の各構成要素(ユニット)を自律分散ユ ニットとし，局所的制約条件を満たすことを目的として 自律的に振る舞う機能をもたせ，マクロオーダーレイヤ 上に全体的整合性(秩序)を実現させることを考える。 制約充足問題の代表例に整合ラベリング問題 (Consistent Labeling Problem : CLP) がある.これは, 複数存 在するユニットそれぞれに，ユニット間の制約(拘束関 係)を満たすようラベル付けを行う問題である。すなわ ち, ユニットの集合, 候補ラベルの集合，ユニットの多 項組(ユニット組)の集合, さらに各ユニット組に対して ラベル付け可能なラベルの多項組の候補(ラベル拘束関 係)の集合が与えられ，すべてのラベル拘束関係を満たす ようなラベル付けを各ユニットに対して行う問題であ る.この整合ラベリング問題は制約充足問題の中でもと 


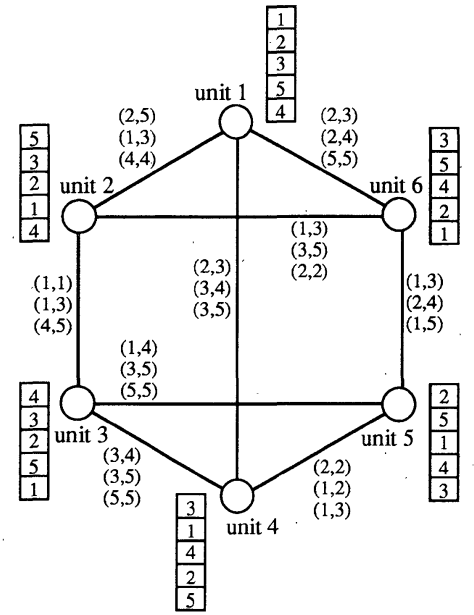

Fig. 4 An example of 2-tuple CLP with preference structure

くに，明確な定義が与えられ多くの研究がなされてい $る^{7)}$.

ここでは，ラベル順序付きの 2 次の同次整合ラベリン グ問題を取り上げる.Fig. 4 にその例題を示す.ラベル付 けが行われる六つのユニットは丸印で表現され，それぞ れに 1 から 5 の整数で表わされたラベル候補がその選好 度(選好順位)の順に上から並べられている。ここでの選 好度とは各ラベル候補に与えられた整数值であって図中 に並べられたラベル群の上から順に選好度 $1,2, \cdots, 5$ と する。リンクで結合されたユニット(ユニット組)間には 制約条件(ラベル拘束関係)が課され, $(\mathrm{a}, \mathrm{b})$ の形式で示 されている(両端の一方のユニットにはラベル $\mathrm{a}$ が，他 方にはラベルbが貼られていれば，この拘束は充足され るとみなされる)。目的は，すべての制約条件を満たし， かつラベルの選好度の合計が最小となるようなラベル付 けを行うことである。

ここでは，六つのユニットをそれぞれ自律分散ユニッ トと考える，マクロオーダープロセスに保持される自律 分散ユニットの内部状態として，各ユニットに対し，五 つのラベルそれぞれに確信値を導入する，つまり，各マ クロオーダープロセスにそれぞれ五つの確信值が保持さ れることになる。ここでの確信值とは, 自律分散ユニッ トがラベル候補中から自身のラベルを選択する際の選択 の有望度を表わす整数值であって，その值が大きいほど 有望であることを表わす（五つのラベル候補の中で最大 の確信值をもつラベルをその時点でのユニットの代表 ベルとする).また，ミクロダイナミクスプロセスは，各 ユニットに対応するラベル拘束関係を参照しながら, 確 信值の変更を行うアルゴリズムによって動作する.

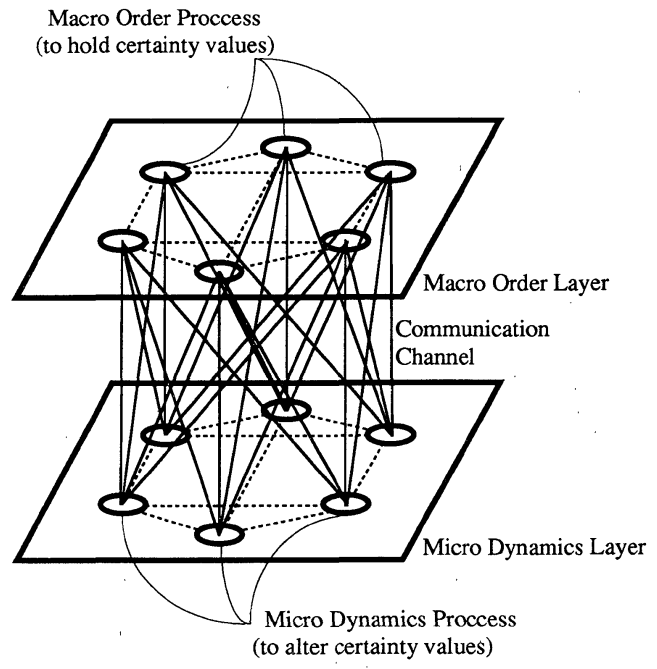

Fig. 5 Program structure for the 2-tuple CLP

ミクロダイナミクスは，各ミクロダイナミクスプロセ スが行う確信值の変更操作に対応する。また，マクロな 秩序の形成は確信值の分布パターンとして出現する。確 信值間の関係が秩序となり，その全体的パターンが問題 の解答を与える.

プログラムの実行過程では，まず各ミクロダイナミク スプロセスがラベル拘束関係にしたがって一斉にそれぞ れの確信值の変更操作を始める.問題の解答を得ようと する全体目標指向性をもつ各ミクロダイナミクスプロセ スの働きによって，マクロオーダープロセスに保持され た確信值の間に局所的に拘束を満たす関係が生まれる。 その後は，各ミクロダイナミクスプロセスがその関係に 支配されながら計算を続けることにより，しだいに秩序 が形成され，スレイビング原理が実現される。

Fig. 5 にプログラム構造を示す. 各ミクロダイナミク スプロセスはすべて等しいプログラムプロセスで，マク ロオーダープロセスもすべて同一である，例題では，す ベてのユニットはほかの三つのユニットと制約(拘束)関 係をもっている(Fig. 4 において各ユニットはほかの三 つのユニットとリンクで結合されている).したがって各 プロセスは，自分自身に対応するプロセスを含めて，合 計 4 個のプロセスと通信可能になっている.

Fig. 6 に, 一つの自律分散ユニット $x$ が $x$ と制約関係 をもつ自律分散ユニット $y$ との間で確信值変更を行う アルゴリズムを示す， $x, y$ それぞれの変更アルゴリズム 適用時点での代表ラベル（最大確信值をもつラベル）を それぞれ $L_{x}, L_{y}$ とする. $L_{x}$ と $L_{y}$ が $x$ と $y$ の間に課さ れた制約を満たせば, 両代表ラベルに対する確信值 $w(x$, $\left.L_{x}\right)$ ならびに $w\left(y, L_{y}\right)$ に, それぞれ両代表ラベルの選好 


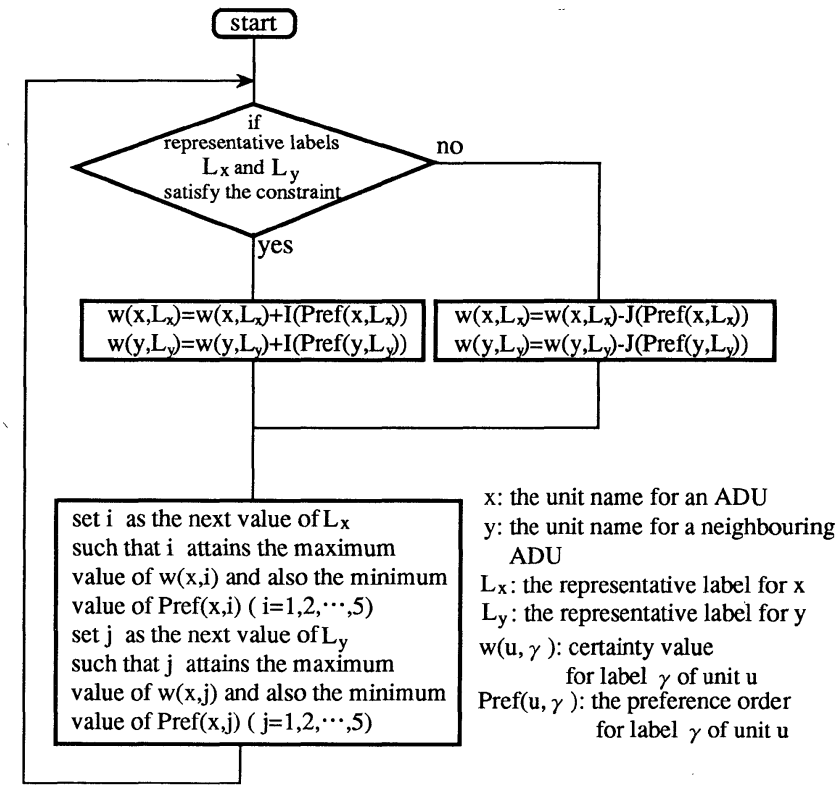

Fig. 6 The Micro Dynamics Process algorithm for the CLP

度 Pref $\left(x, L_{x}\right), \operatorname{Pref}\left(y, L_{y}\right)$ を関数 $I$ に代入した值 $I$ $\left(\operatorname{Pref}\left(x, L_{x}\right)\right), I\left(\operatorname{Pref}\left(y, L_{y}\right)\right)$ を加える。もし制約を 満たさなければ関数 $J$ に代入した值を減ずる。ここで, $I, J$ は選好度を引数とする関数で，定義域 $\{1,2,3,4,5\}$ に対して正の整数を返す. $I$ は単調減少, $J$ は単調増加の 関数である。すなわち，その時点での代表ラベルのペア が制約を満たしていれば選好度の高いラベルほど確信值 の増加が大きく, 制約を満たしていなければ選好度の低 いラベルほど確信值の減少が大きくなるように設定され ている。これは，なるべく選好度の高いラべルを採用す るという全体目標指向性の実現のためである。さらに， 制約を満たしていれば確信值を上げ，満たしていなけれ ば下げるという操作は，やはり問題を解くという全体目 標指向性を表わすものである．またこのアルゴリズムで は，あるユニットの代表ラベルの確信值が大きくなり変 更がなくなると，隣接するユニットの代表ラベルはその 固定された代表ラベルに対応した制約を満たすものに変 更されていくことになる。この性質は，自己触媒性の実 現を意味している。実際のプログラムでは, このアルゴリ ズムを自分のユニットと制約関係をもつすべてのユニッ トに対して繰り返し適用している.

Fig. 7 (a) は，最終的に得られた結果である.網のか かった部分が選択されたラベル(代表ラベル) と充足され た制約を表わしている．9本のリンクそれぞれに課され た制約がすべて充足されており，本例題における最適解

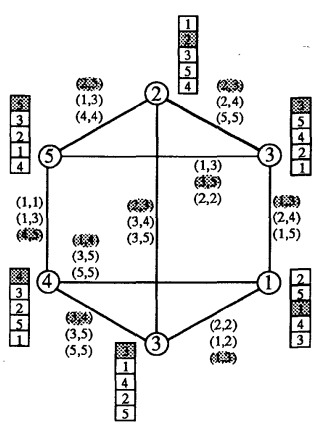

(a) Result of computation

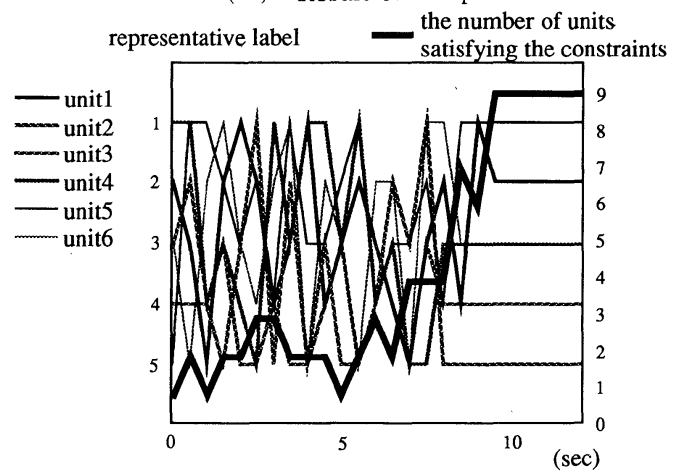

(b) Transition of representative labels and the number of units satisfying the constraints

Fig. 7 The resultant state and the process of computation for the CLP 
が得られている.Fig. 7(b)にシステムの計算実行過程 を示す。細い線が各自律分散ユニットの代表ラベルの変 更過程を示している。また，太い実線がシステム全体で 充足されている制約の数の時間推移を示しており，最終 的に九つすべての制約を満たした状態に至っている。こ の図から，各ユニットの自律的振る舞いとその中からシ ステム全体の整合性が生成される様子がわかる。

本システムは一度のパラメー夕設定で Fig. 4 と同形 式の多くの問題設定に対して有効であったが，それと同 時にシステム全体の挙動は，Fig. 6 のアルゴリズム中の パラメータ值 $I, J$ を調整することによってさまざまに 変化した。つまり，自律分散ユニット自体の機能を損な うことなく，その関係性を制御するパラメータの調整の みによって秩序形成の調節が可能であった。これは，ミ クロダイナミクスプロセス内アルゴリズムによる制御の みでは確定されない境界条件をパラメー夕調整によって 制御するもので，周縁制御の原理が成立しており，多数 の自律分散ユニットのミクロダイナミクスを単一の変数 で制御することが可能となっている.

\section{2 多自由度制御問題に対する構築例}

ここで多自由度制御問題とは, 多くの操作変量からな る大規模システムを，各変量を制御することにより，シ ステム全体の整合性を保ちつつ動作させる問題である.

この種の問題では, 各操作 (変量)の自律性とシステム 全体の整合性をともに考慮した上で制御を行う必要があ る。提案システムを適用するためには, 多自由度制御問 題の各(操作変量への)操作をミクロダイナミクスプロセ スと考え，自律的に動作する機能をもたせ，マクロオー ダーレイヤに全体の整合性(秩序)を実現させるという方 法が考元られる。

ここでは，例題として信号機群による交通制御問題を 取り上げる.一本の道路に 20 個の信号機が設置されてい るものとする. 信号機は青, 黄, 赤と点灯を繰り返し, 青に点灯しているときにのみ車両が通行できるものとす る.ここで青, 黄, 赤の点灯継続時間はすべて等しいも のとした．各信号機の点灯の周期は一定であり, 車両の 通行状況に応じてその位相を自律的に変化させ, 車両の 通行に対して制御を行うことができる，ただし，位相を 調節するときに限り青, 赤, 黄の点灯継続時間は等しく なくともよいとする。このような道路に対し，その左端 から一定速度かつ等間隔で車輛を流入させるものとす る.この例題では, 各信号機の自律的制御機能をミクロ ダイナミクスプロセスと考える.

信号機それぞれが車両に対して行う制御動作が, Fig. 1 (c)でのミクロダイナミクスに相当する. 各信号機は隣 接する信号機から車輌の流れを介して情報を受けとるこ

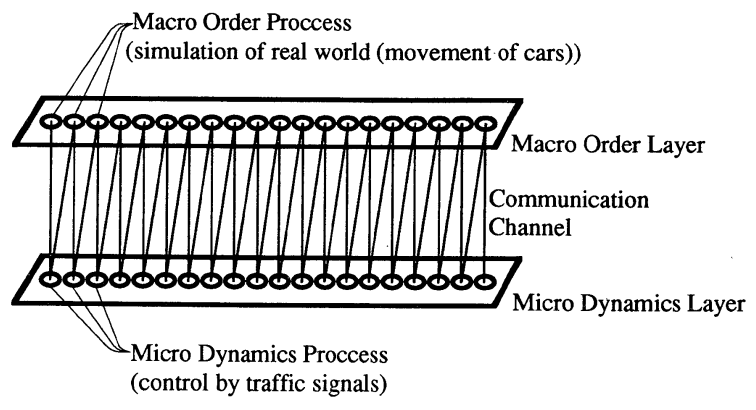

Fig. 8 Program structure for a traffic control problem

とになる。これに対してマクロな秩序は, 車輛の流れが つくる全体的パターンである．車輛の流れが円滑なもの になれば，その全体的パターンも秩序だったものになる と考元られる。さらに, 秩序だった車輛の流れは, 秩序 だった信号機の点灯パターンとして反映される。

このようなミクロダイナミクスとしての各信号機の動 作と，マクロな秩序としての車輛の流机もしくは信号機 の全体的点灯パターン, との間でフィードバックループが 形成され，スレイビング原理が成り立つ。各信号機が一 斉に制御を始めると, 車輛の動き方に応じて, 徐々に信 号機群の点灯パターンに関係(秩序)が生じてくる.つぎ に各信号機が，いったん生じた関係に支配される形でみ ずからの制御を行い，さらなる秩序を形成することにな る.

Fig. 8 にシステム構成を示す.ミクロダイナミクスレ イヤ中に丸印で示した各ミクロダイナミクスプロセスは 信号の制御機能を規定したプログラムであり，マクロ オーダーレイヤ中の丸印は車の動きをシミュレートした もので, 本例題ではこのプログラムがマクロオーダープ ロセスを構成することになる。ただし実際の信号制御に 適用する場合には，マクロオーダープロセスにはミクロ ダイナミクスプロセスによって制御される現実の世界を 対応させなければならない。

つぎに，一つのミクロダイナミクスプロセスの機能を 説明する．この具体例では，すべてのミクロダイナミク スプロセスすなわち信号機は，全く同じプログラムでで きており，Fig. 9 にその概念図を示す．各信号機にとつ て, 車の停止を少なくするという観点から, 車の到着す るタイミングとして最も好ましいのは同図における丸印 の瞬間である。すなわち，青が点灯している区間の丁度 中央点である.ここでたとえば, Fig. 9 の上段の×印で車 が到着したとする。この場合，黄が点灯している区間で あるから，車両は当然つぎの青の点灯まで停止しなけれ ばならない．このとき信号は，つぎにも前回と同じ×印 のタイミングで車両が到着した場合, 青の点灯区間の丁 


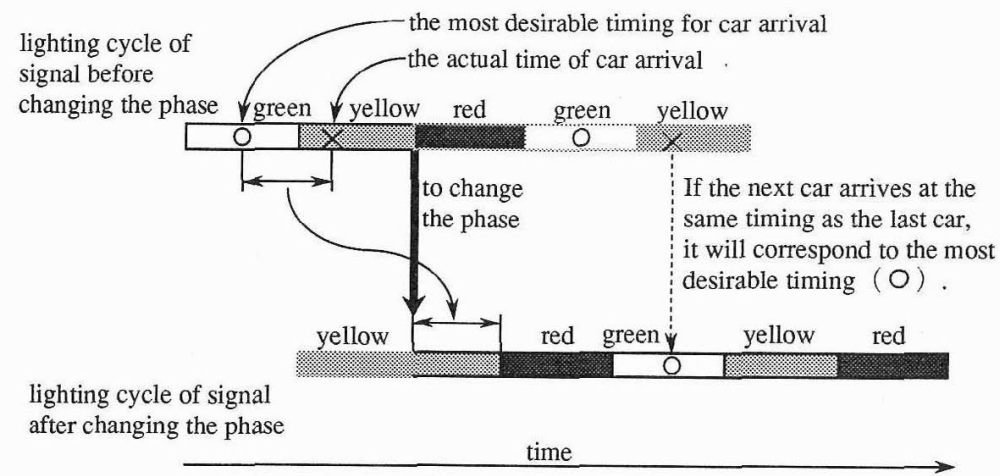

Fig. 9 Illustration of the Micro Dynamics Process algorithm for the traffic control problem

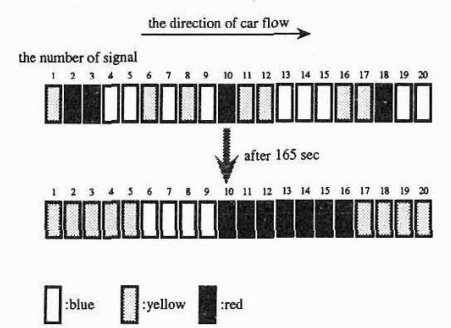

(a) Transition of lighting patterns of signals

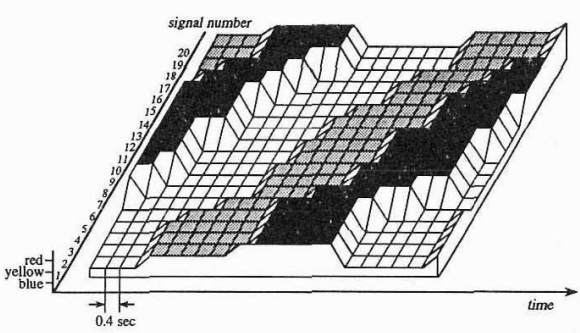

(b) Lighting pattern of signals after the order formation

Fig. 10 Formation of the order in lighting patterns for the traffic control problem

度中心点に当たるように，点灯の位相をずらす操作を行 う。すなわち，丸印に対応する時刻と×印に対応する時 刻の差の分だけ，位相を調節する (Fig. 9 の下段).

繰り返し述べているように，各ミクロダイナミクスプ ロセスの機能を設定する際に重要なことは, 全体目標指 向性と自己触媒性をあ放せもたせることである。信号機 のプログラムの場合では, 位相をずらすことによって車の 到着を青の点灯区間に合わせることは, 信号での停止回 数をなるべく減らすためのもので全体目標指向性をもつ ことに相当する。また,隣接する信号機の制御を受けた車 の動きに自己の制御を合わせてゆくアルゴリズムでもあ り，自己触媒性をもあわせもつものであることがわかる。

Fig. 10 にその実行結果の一例を示す.プログラムを実 行した初期段階では, 各信号機はランダムに点灯してい る(Fig. 10(a)の上段)。その後, スレイビング原理にし たがって各信号の点灯の間に関係ができ, 最終的に秩序 だったパターンとなる(Fig. 10 ( a )の下段). Fig.10（b ） は秩序が形成された後の信号機群の挙動を示したもの で，信号機間の点灯の関係に帯状の秩序パターンが見ら れる。このパターンは, 主に車の速度に対応するパラメー タを調節することによってさまざまに変化する. Fig. 11

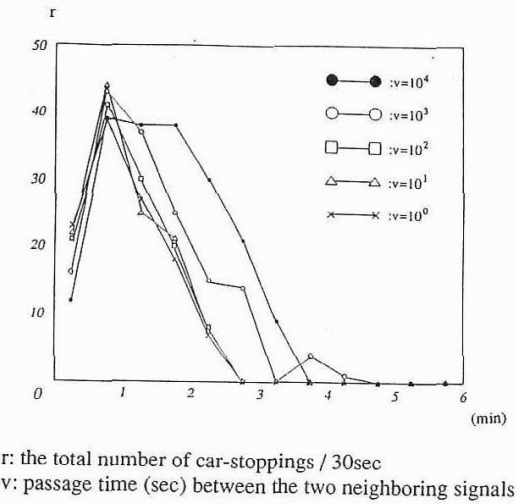

Fig. 11 Relation of the total number of car-stoppings with the elapse of time and the car speed

は，信号機によって車輛が停止させられた回数の時間推 移を示したものである。この值が小さいほど信号で停止 する車輛は少なく，したがってシステム全体の秩序の程 度もより高いといえ, 時間の経過とともに秩序の達成さ れていく様子がわかる．また，一般に車輛の速度が小さ いほど秩序の形成も遅れることがわかる。

この例では，信号の周期は一定である，したがって， 


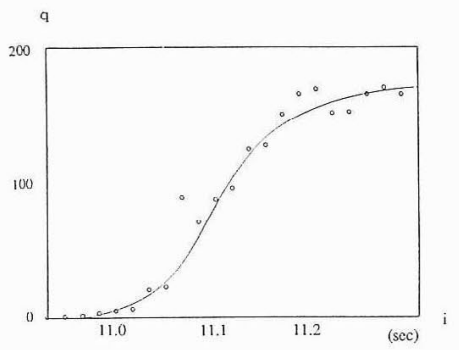

q: average number of car-stoppings in the total course i: time interval of cars' starting

Fig. 12 Relation of the average number of car-stoppings and the time interval of cars' starting

車輛の左端への流入間隔によっては当然対応しきれな い. Fig. 12 は, 車輌の流入間隔 $i$ と車輌の停止回数 $q$ の 関係を示すものである. 流入間隔 $i$ の值によっては秩序

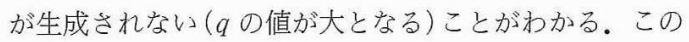
ようにプログラム中のパラメータを調節することによっ て, 秩序の出現の有無が決定される。これは, 各ミクロ ダイナミクスプロセスの機能に矛盾することなく, 秩序 生成にかかわる周縁制御を行うもので, 二重制御を実現 していることを意味している。

\section{6. むすび}

本研究では, スレイビング原理に基づいて問題解決を 行う自律分散システムの構成原理を提案し,いくつかの 問題解決に即して具体的にシステム構築を行った. そこ では, 自己触媒性, 全体目標指向性, 階層性, 二重制御 および周縁制御の原理が中心的概念であった。

提案システムは, “自律”と“協調” の共存が実現され, 統一管理機構が存在せず, 構成要素間の相互作用のみに よって秩序が生成されるなど自律分散システムに要求さ れている特性が満足されており，第 1 章で述べたような 様々な効能が期待できる。しかし，提案システムの適用 例の問題設定が現在のところ特殊なため, 性能比較に適 当なほかのシステムが見当たらないことから，こ机ら効 能の定量的評価は難しいと考えられる。

本論文では自律分散システムに最低限必要であると考 えられる二層構造のシステムについて述べたが，今後よ り一般的なものとしてミクロダイナミクスレイヤとマク ロオーダーレイヤを交互に重犼た多階層構造の構成概念 の導入を検討している。二層構造のシステムではマクロ オーダーレイヤに局所的な秩序が複数共存する現象(秩 序のクラスタ化条)がみられる.この局所的・断片的な秩 序をより上位の階層における自律分散ユニットであると 捉え多階層のシステム構築を行えば, 生物界の階層構造
とのアナロジーがより強く，またさらに複雑な問題解決 が可能なシステムの構築が可能になると考えられる。

最後に, 有益なご指摘を賜りました校閲者の方に深く 謝意を表します。

\section{参 考 文 献}

1）特集：分散と協調，計測と制御，26-1 (1987)

2）伊藤正美：自律分散システムはいかにして構成されるか, 計測と制御， 29-10，877/881 (1990)

3）長田正：自律分散システムと情報処理，計測と制御，2910, 59/62 (1990)

4) H. ハーラン著, 牧島邦夫, 小森尚志訳：協同現象の数理 : 物理, 生物, 化学的系に括ける自律形成, 東海大学出版 (1980)

5) M. ポラニー著, 佐藤敬三訳 ; 暗黙知の次元, 紀伊國屋書 店, 51/81 (1980)

6) Pountain, D. and May, D. : A Tutorial Intoroduction to Occam Programming, INMOS Limited (1987)

7) Haralick, R. M. and Shapiro, L. G.: The Consistent Labeling Problem Part I, IEEE Transactions on Pattern Analysis Machine Intelligence, PAMI-1-1, 173/ 184 (1979)

8) 清水, 山口, 矢野: 自律分散制御の理論について, 第 7 回 自律分散システム研究会講演論文集，1/12（1988）

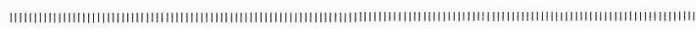

$$
\text { [著 者 紹 介] }
$$

\section{増 市博 (正会員)}

1989 年, 京都大学工学部精密工学科卒 業. 91 年同大学院精密工学専攻修上課程修 了. 同年より富士ゼロックス(株) 総合研究 所システム技術研究所 (現 システム・コミ ユニケーション研究所) 入所, 現在に至る. システム工学, 知識情報処理, とくに協調 計算の研究に従事.

片 井修（正会員）

(Vol. 28，No. 1 参照)

椹 木 哲 夫(正会員)

(Vol. 28, No. 1参照)

西 山高 史 (正会員)

1986 年, 京都大学工学部精密上学科卒 業. 91 年同博士課程単位取得退学. 同年松 下電工(株)インフォメーションシステムセ ン夕 AI 研究室勤務. 分散並列処理システ ム, ロボティタスに関する研究開発に従事.
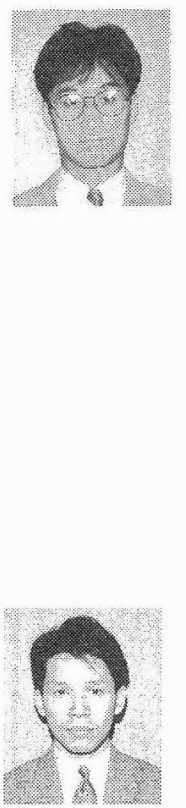

岩 井 壮介 (正会員)

(Vol.28, No. 1 参照) 